\title{
"Daringly, yet with Reverence": Pearse, Mickiewicz and the Theology of National Messianism
}

\section{Maciej Ruczaj}

\section{(2) OpenEdition \\ 1 Journals}

\section{Electronic version}

URL: http://journals.openedition.org/etudesirlandaises/3744

DOI: 10.4000 /etudesirlandaises.3744

ISSN: 2259-8863

\section{Publisher}

Presses universitaires de Caen

\section{Printed version}

Date of publication: 30 June 2014

Number of pages: $57-71$

ISBN: 978-2-7535-3449-0

ISSN: 0183-973X

\section{Electronic reference}

Maciej Ruczaj, «"Daringly, yet with Reverence": Pearse, Mickiewicz and the Theology of National Messianism », Études irlandaises [Online], 39-1 | 2014, Online since 30 June 2016, connection on 10 December 2020. URL : http://journals.openedition.org/etudesirlandaises/3744 ; DOI : https://doi.org/ 10.4000/etudesirlandaises.3744

\section{(c) (1) (ㅇ)}

Études irlandaises est mise à disposition selon les termes de la Licence Creative Commons Attribution - Pas d'Utilisation Commerciale - Partage dans les Mêmes Conditions 4.0 International. 


\title{
"Daringly, yet with Reverence": Pearse, Mickiewicz and the Theology of National Messianism ${ }^{1}$
}

\author{
Maciej RucZaj \\ Centre for Irish Studies, Faculty of Arts, Charles University in Prague
}

Abstract

The article attempts to apply the elaborate theory of Polish romantic messianism to the rhetoric of Patrick Pearse, frequently - yet without further specifications - characterized as "messianistic". Pearse's writings are analyzed alongside those of the central figure of Polish nationalist messianism - poet Adam Mickiewicz - whose texts were discovered by the Irish nationalist press in the years preceding the Easter Rising. The argument focuses mainly on the theme of the redemptive sacrifice and the attempts of both authors to balance its theological roots and revolutionary, "heretical", potential.

Keywords: Influences/intertextuality; Patrick Pearse; Adam Mickiewicz; Easter Rising (1916); Irish nationalism

\section{Résumé}

Cet article essaie d'appliquer la théorie élaborée du messianisme romantique polonais à celle de Patrick Pearse qui est fréquemment - mais sans spécifications précises - caractérisée comme "messianiste ". L'écriture de Pearse est analysée à côté de l'écriture de la figure centrale du messianisme national polonais - Adam Mickiewicz. Les textes de ce dernier ont été découverts par la presse nationaliste irlandaise dans les années qui ont prédédé l'Insurrection de Pâques. Les arguments se concentrent notamment sur le sujet du sacrifice rédempteur et l'effort des deux auteurs d'équilibrer ses racines théologiques et son potentiel révolutionnaire et " hérétique ".

Mots clé : Influences/intertextualité; Patrick Pearse; Adam Mickiewicz; insurrection de Pâques (1916); nationalisme irlandais

Quoting the notorious ending of Patrick Pearse's play The Singer - widely understood as a dramatic summary of the ideology of messianic blood sacrifice that motivated the leader of the Dublin Easter Rising of 1916 - Augustine Martin comments with apparent relief: "[F]ortunately, I am not required, in the context, to examine the theological implications of these strange lines ${ }^{2}$."

1. This article was written thanks to the support of the Grant Agency of Charles University in Prague.

2. Augustine Martin, "To make a right rose tree. Reflections on the poetry of 1916", Studies, Spring 1966, p. 38-50. 
Although de Valera's Ireland upholds the image of Pearse as an unproclaimed Catholic saint and a "holy martyr of Irish freedom", those "strange lines" stating that "one man can free a people as one Man redeemed the world" remained deeply problematic - and tacitly omitted - for the Catholic audience. The attention of the readers and authors, from the post-Rising issues of The Catholic Bulletin through Pearse's hagiography by Louis Le Roux right up to the commemorative celebrations of 1966 when Augustine Martin's article was written, consequently centred on the personal devotion and moral virtues of the main ideologist of the insurrection rather than the theological conundrums of his texts.

Only a few years after the $50^{\text {th }}$ anniversary of the Rising did Studies publish Fr. Francis Shaw's denunciation of Pearse's "national heresy", confronting nationalist with Christian orthodoxy and declaring their antithetical character. Shaw stated that Pearse's "equation of the patriot with Christ is in conflict with the whole Christian tradition" and classified his "gospel of Irish nationalism" as "essentially a gospel of hate"

Shaw's text opened the debate about the theological dimension of Pearse's thought and its uneasy relation to the Catholic doctrine. Pearse's fascination with the redemptive sacrifice of Christ, visible in the above-quoted ending of The Singer, naturally directed the attention towards the messianic quality of his thinking. "Messianism" has become one of the key-words of Pearsean scholarship. To mention only some of the prominent early voices in Irish Studies, F.S.L. Lyons described Pearse's ideas as a culmination of the "messianic strain" in Irish writing and Patrick O'Farrell spoke of Pearse as "the first Irish rebel to have made explicit and substantial use of the messiah concept". It seems, however, that the term "messianism" is generally taken for granted and the Pearsean variety of this universal phenomenon has rarely been located within any comparative or theoretical context. Among the exceptions we must mention Patrick O'Farrell and Sean Farrell Moran who for the first time spoke about Irish Catholic nationalism in the context of millenarianism - a historical phenomenon defined by such scholars as Norman Cohn ${ }^{6}$. O'Farrell points out that the Easter Rising was the first Irish rebellion directly related by its speakers to the "Christian concepts and imagery" and links this phenomenon to the legacy of the devotional revolution of the second half of the previous century (in accordance with Cohn's precept that the emergence of millenarian attitudes

3. Patrick Pearse, "The Singer", The Literary Writings of Patrick Pearse, ed. Séamas Ó Buachalla, Dublin, Mercier Press, 1979, p. 125.

4. Francis Shaw SJ, "The Canon of Irish History - a Challenge”, Studies, Summer 1972, p. 115-153.

5. F.S.L. Lyons, Culture and Anarchy in Ireland, 1890-1939, Oxford, Clarendon Press, 1979, p. 88; Patrick O’Farrell, "Millenialism, Messianism \& Utopianism in Irish History", Anglo-Irish Studies n 2, 1976, p. $45-68$.

6. Norman Cohn, The Pursuit of the Millennium. Revolutionary Messianism in Medieval and Reformation Europe and its Bearing on Modern Totalitarian Movements, New York, Harper \& Row, 1961. 
is always preceded by a wave of "new piety" and strengthening of lay participation in devotional practices). Sean Farrell Moran also locates Pearse's discourse of a martyr's death for Irish freedom in the millenarian context. According to Moran, the "archetypal Irish patriot", as created by Pearse, "re-enacts a redemptive myth", combining in his Christ-like act the role of the sacrificer and the offering. The argument is based on a comparison between Pearse's "political theology" and the millenarian suicidal concept of martyrdom of the donatist sect from the late Roman period ${ }^{7}$. This very distant point of reference - though proving a firm position of the revolutionary messianism within the Christian mindset - may be, however, exchanged for a much closer one.

Pearse's first critical biographer, Ruth Dudley Edwards, claims that he "owed more to the Romantics than to Christianity, in whose institutional theology he had little interest ${ }^{8 \prime}$. In the following paragraphs, I would like to show that a comparative and theoretical context for Pearse's ideology may be provided by the Romantic Polish messianism of Adam Mickiewicz. Poland claims the status of "the homeland of century messianism" just as "France is home of the Enlightenment" and "Germany of romantic conservatism" and due to the centrality of the theme in Polish intellectual history, Polish humanities have managed to generate specific definitions and tools for analysing this notoriously elusive phenomenon. Most importantly, however, Polish messianism provides a fertile comparative ground due to its deep engagement with Catholic theology and symbolism, in many respects prefiguring the controversies created by Pearse's heterodox employment of Christian sanctities to serve the national cause. My discussion of Pearse in this context is going to start with an outline of the modern variety of Catholic millenarianism as represented by Mickiewicz. Subsequently, it addresses the discovery of Mickiewicz's writings in pre-Rising Ireland in order to test Pearse's ideas against Mickiewicz's "ideal type" of revolutionary messianism - at once national and deeply Catholic.

\section{Christ of Nations}

The upheaval of the French Revolution and Napoleonic wars triggered the "general messianistic atmosphere across Europe". It was the "expectation of universal regeneration" that was a driving force for individuals, social movements and nations in the first half of the nineteenth century. At the same time, the universalist elements in the Romantic messianism (secularised versions of medieval millenarian movements) were concomitant with the exaltation of the specific national

7. Sean Farrell Moran, "Patrick Pearse and Patriotic Soteriology", Irish Terrorism Experience, ed. Y. Alexander and A. O’Day, Dartmouth, Aldershot, 1991, p. 9-28.

8. Ruth Dudley Edwards, Patrick Pearse. The Triumph of Failure, Dublin, Irish Academic Press, 2006, p. 201.

9. Andrzej Walicki, Mesjanizm Adama Mickiewicza w perspektywie porównawczej, Warszawa, IBL, 2006, p. 31. 
communities conceived as bearers of the messianic mission, in analogy to the biblical motif of the "elected nation ${ }^{10 "}$.

Jacob Talmon - the major Western historian of modern political messianism (probably not incidentally a Polish Jew by birth) lists Adam Mickiewicz, the greatest poet of Polish Romanticism, among three major European prophets of national messianism, along with Jules Michelet and Giuseppe Mazzini ${ }^{11}$. Following the brutal suppression of the November Rising (1830-1831) by Imperial Russia which annihilated the last remnants of the autonomy of what was once a mighty kingdom, Mickiewicz formulates a new concept of "Polishness" fit for the nation of exiles, tying it to the idea rather than the territory and attempting to exchange despair for the hope for regeneration. In his poetic drama Forefathers' Eve, he invokes for the first time the concept of the redemptive power of sacrifice by patriots as well as a vision of the Messianic leader - "Freedom's viceroy on earth incarnated". A year later, in the mystical prose Books of the Polish Nation and Pilgrimage, Mickiewicz's vision acquires a clearer outline, with its central idea of Poland as the "Christ of nations" destined to bring universal freedom through its suffering:

And the Polish nation was crucified, and brought into its tomb. And the kings shouted: "We have killed freedom - we have buried it." And their shouting was but folly. [...] [F] or the Polish nation is not dead! Its $b o d y$, indeed, is in the tomb, but its soul has ascended from the surface of the earth; that is, from public life to the abyss, or domestic life - to the homes and hearths of those who endure distress and oppression in their country, and far from their country, in order to be the witness there of their suffering, and of their misery. And on the third day, the soul shall return to its body; and the nation shall rise from the dead; and shall free all the nations of Europe from slavery ${ }^{12}$.

Taking Mickiewicz as an "ideal case" of Romantic messianism, Polish scholars attempted to identify some key features of the concept. Firstly, like its Christian millenarian predecessors, Mickiewicz's messianism is based on the belief in the decisive transformation leading to the state of social or moral perfection of mankind. It is a quest "for total, imminent, ultimate, this-worldly, collective salvation ${ }^{13}$ ". Special emphasis is to be placed on the words "this-worldly" and "collective", both contradicting the orthodox Christian view of history and instead referring back to the heretical millenarian movements which elaborated upon the

10. Jacob Talmon, Political Messianism. The Romantic Phase, New York, F.A. Praeger, 1961, p. 15; Andrzej Walicki, Filozofia a mesjanizm, Warszawa, PIW, 1970, p. 16.

11. Talmon, op. cit., p. 266-268.

12. Adam Mickiewicz, "Księgi narodu i pielgrzymstwa polskiego", Dzieła 2, Warszwa, Czytelnik, 1983, p. 223.

13. Walicki, Filozofia i mesjanizm, p. 10. 
visionary image of the earthly Thousand Year Kingdom of Christ and His Saints mentioned in Apocalypse. Secondly, the transformation is to be mediated through the elected nation or group or individual, the bearer of the messianic mission. Finally, the election is conditioned in most cases by undergoing a period of trial and suffering comparable to the Passion of Christ. Millenium, mission and passion thus form three pillars of the messianic vision ${ }^{14}$.

Romantic messianism is a phenomenon residing on the interface between religious and political consciousness: it naturally arises from the Bible, with its Old Testament concept of the elected nation and of the personal messiah of the Gospel, yet its attitude towards religion remains ambiguous at best. Jacob Talmon argues that "all Messianic trends considered Christianity, at times religion as such, always the historic form of Christianity, as the arch-enemy. Indeed they triumphantly proclaimed themselves substitutes for it ${ }^{15}$ ". From the perspective of Polish Romanticism however it is not possible to make such a definitive statement. Although most scholars would agree that messianic tendencies can be viewed as challenging the authority of the Church, at the same time Mickiewicz's writing remains deeply rooted in Catholic symbolism and vocabulary and he attempts to balance its heretical potential and orthodox background ${ }^{16}$.

\section{Mickiewicz and Ireland}

The fact that Mickiewicz received quite considerable attention in the Irish nationalist press in the years and months preceding the Easter Rising has hardly ever been mentioned in the analyses of the Irish intellectual milieu of the time. "Translations from Mickiewicz" appeared first in the separatist monthly Irish Freedom in August 1914, signed by GiollaEireann, a pen-name for young nationalist activist Aodh de Blácam. A year later, de Blácam published a lengthier text on Mickiewicz in Arthur Griffith's paper Nationality. De Blácam further provided a few short English translations from The Books of the Polish Nation and his articles inspired Liam Ó Rinn to begin translating The Books into Irish ${ }^{17}$. The first fragments of his translation appeared in Nationality on a weekly basis from February to April $1916^{18}$.

14. Paweł Rojek, "Mesjanizm integralny", Pressje, n 28, 2012, p. 20-49.

15. Talmon, op. cit., 25.

16. In this article I am concerned with the so-called "national" phase of Mickiewicz's messianism, connected with The Books of the Polish Nation and Forefathers Eve. According to Walicki and other commentators, Mickiewicz's views drifted towards a more heterodox (and at the same time more universalistic) vision of history in the later period of his life (from around 1840).

17. In fact, both de Blácam's and Ó Rinn's translations were made from the French translation, not the Polish original.

18. The story of Mickiewicz's reception in the nationalist press of the time is recounted in detail in the introduction to the unpublished doctoral thesis by Mark Ó Fionnain from the Catholic University of Lublin (Translating in 
The main reasons for such an interest were obvious: "The two countries are alike in manners, in ideas, in faith, and in misfortune. The same methods of oppression have been used against each" - says de Blácam in his article dated July $1915^{19}$. In March 1916, he even calls Poland - "Ireland of the East". Nevertheless, the community of fate was in this case rooted in the intimations of a deeper relation between two nationalisms.

De Blácam's article is fittingly entitled (if we keep Pearse in mind) "Poland's Resurrection and its Prophet”. Attempting to introduce Mickiewicz's ideas to the Irish public, de Blácam quotes the above-mentioned excerpt of The Books and adds:

What may be called the eschatology of Messianism was this dream of Mickiewicz that Poland was a nation chosen by God to be slain as victim for liberty, her resurrection would bring the end of tyranny throughout Europe. Daringly, yet with reverence, the drama of Poland's destruction by the Powers is compared [...] to the drama of Calvary ${ }^{20}$.

De Blácam's summary highlights the crucial features of Mickiewicz's messianism: the eschatological character, the centrality of the sacrificial theme set in the context of Christ's death and resurrection and the overall uneasy relation to Catholic orthodoxy, alluded to in the words "daringly, yet with reverence".

Obviously, a very similar set of key motifs can be found in the writing of Patrick Pearse. This article does not aim at proving a direct influence of the Polish poet on "the mind behind the Easter Rising". Still, it is highly improbable that in the rather limited microcosm of the Dublin separatist press Pearse would not have come across Mickiewicz's texts. On the other hand, he neither mentioned the name in his writings nor quoted any of the above-mentioned articles. Nevertheless, the chronological coincidence, as well as the deeply reaching parallels, justify the comparison of the respective authors. Setting Mickiewicz alongside Pearse helps to solve the oft-invoked but rarely explained issue of Pearsan messianism and provides us with a comparative framework of the relation between mystical revolutionary nationalism and Catholic orthodoxy, which proved so disturbing to both Catholic and non-Catholic commentators of his writings.

Times of Political Turmoil: Liam Ó Rinn's Irish Language Translations of Adam Mickiewicz's Księgi Narodu Polskiego i Pielgrzymstwa Polskiego, Lublin, 2010) dedicated primarily to the linguistic and comparative analysis of Ó Rinn's translation. To the best of my knowledge, this is the only work dealing with the subject to date. 19. Aodh de Blácam, "Poland's Resurrection and its Prophet", Nationality, July 24, 1915, p. 6-7.

20. De Blácam, op. cit. 


\section{Anatomy of messianism}

Romantic philosophy provided a fertile ground for the evolution of various modes of national messianism. Pearse shared with Mickiewicz its basic ethical, ontological and epistemological precepts, as well as its vision of history and of individual acting in history, which altogether formed a set of necessary preconditions for the emergence of messianic attitude.

First of all is ethical radicalism confronted with the conformism of the majority: the attitude described by Pearse as "wise foolishness of the saints ${ }^{21}$ ", disrespectful of

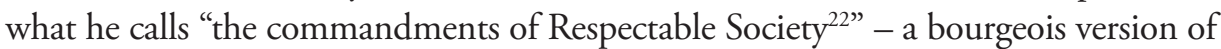
the Decalogue, the first of which is "you shall not be extreme in anything". Secondly, the repudiation of rationalism, connected in their thinking with the soulless, the mechanical and the commercial and juxtaposed with "feeling and faith", is - as Mickiewicz's poem testifies - superior to the "savant's glass and eye". "The spiritual always triumphs over the actual (for the spiritual, being the true actual, is stronger than the forms and bulks of the actual)" - adds Pearse ${ }^{23}$. The antithetical pairs defining their ethics and epistemology are transposed, brought onto a higher, collective and political, level in the form of a juxtaposition of freedom and despotism (Mickiewicz) and nation and empire (Pearse). The nation is - quite understandably when taking into consideration the history of Poland and Ireland - conceived primarily as a spiritual idea, alive even if temporarily devoid of its "body" (i.e. the State), and bound together by "natural ties, ties mystic and spiritual, and ties human and kindly". Its antithesis is "the rule without love" (Mickiewicz), "held together by ties of mutual interest" or "brute force" (Pearse $\left.{ }^{24}\right)$. To serve the cause of this holy fellowship requires - finally - moral perfection (or at least striving for it) and evangelical virtues, as summed up in O'Rossa's graveside oration ("Splendid and holy causes are served by men who are themselves splendid and holy") or in Mickiewicz's Books: "You shall be risen from the tomb, because you have faith and love and because hope lives in you ${ }^{25}$."

The messianic concept - although rooted in a specific ontology and epistemology - is primarily a vision of time and history. Andrzej Walicki distinguishes with reference to Mickiewicz between the romanticism of tradition (exemplified in the nineteenth century by, for example, Russian slavophiles and - it might be

\footnotetext{
21. Pearse wrote in 1913 and 1914 a series of essays entitles "From the Hermitage" where he assumes the pose of a hermit juxtaposing the false wisdom of "the world" and the real knowledge of the "holy fool".

22. Patrick Pearse, An Macaomh 2, 2 May 1913, p. 8.

23. Patrick Pearse, "By Way of Comment", A Significant Irish Educationalist: The Educational Writings of P.H. Pearse, Dublin, Mercier Press, 1980, p. 335.

24. Patrick Pearse, “O’Donovan Rossa: Graveside Panegyric", Political Writings and Speeches, Dublin, Maunsel \& Roberts, 1922, p. 136.

25. Patrick Pearse, "The Sovereign Nation", op. cit., p. 343; Adam Mickiewicz, op. cit.
} 
added - in the Irish context by the Catholic mainstream of Irish Ireland) and the messianic romanticism of charisma. Both share contempt for the rationalism of bourgeois society, yet whereas the former holds the position of the guardian of the past, aiming to protect or restore it, the latter starts off by glorifying the past yet finally turns into a future-oriented, creative and revolutionary force. This vision of history follows the theological paradigm which is deeply dynamic: primordial bliss, the fall, suffering endured by the community and expected redemption. Romanticism of charisma bridges the past and the future, paradise lost and paradise regained (skipping with contempt the present moment), "giving new meanings to old elements and clothing the new ones with traditional connotations ${ }^{26}$. In Pearse's case, this convoluted relation to tradition may be exemplified at every stage of his activity, from his attitude to the heritage of Irish literature (he struggles with antiquarians arguing for the need to rise simultaneously "the banner of the Ancients" and "the banner of Liberty ${ }^{27 ", ~ i . e . ~ t o ~ c o m b i n e ~ t h e ~ r e s p e c t ~}$ for the past with the response to the individuality of the author and the dilemmas of the modern age, to modernize Ireland but "on our native terms", to the progressive educational methods he implemented at St. Enda's school, disguised however by the ethos of the mythical "boy corps of Emain Macha" derived from the medieval epic.

Simultaneously nostalgic and futurist, the logic of the romanticism of charisma which joins the past and the future of the community into a dynamic and synthesising whole finds its realization in the vision of the hero of the nation. To unfold itself in time, the messianic vision requires a bearer and agent. The Romantic thought generally inclines towards the exaltation of outstanding individuals who - as both Carlyle and Mickiewicz claim - are the founders of communities, moving principles of history and, through their cult, providing the glue that holds society together. As the great theoretician of hero-worship Stefan Czarnowski claims, a heroic figure is an incarnation of the idea of collectivity ${ }^{28}$. Thus, his role is revelatory (awakening and incarnating the hidden essence) and synthetic $^{29}$ (representing the community as a whole). Pearse's auvre is inevitably centred on different heroic figures, both historical - such as the revolutionary leaders Wolfe Tone and Robert Emmett - and legendary, like the warrior Cú Chulainn from the Ulster Cycle. Crucially, he presents these individuals as emanating the spirit of the nation, attempting to incorporate within their cult sometimes very

26. Walicki, Filozofia i mesjanizm, p. 292.

27. Patrick Pearse, "In My Garden”, An Claideamh Soluis, August 4, 1906.

28. Stefan Czarnowski, Kult bohaterów i jego spoteczne podtoże. Św. Patryk jako bohater narodowy Irlandii, trans. A. Glinczanka, Warszawa, PWN, 1956, p. 16-17.

29. Significantly, Pearse's last essay, "The Sovereign Nation" ends by describing his writings as "the necessary synthesis" of the various strains of Irish nationalist thought. 
distant traditions, pairing bloodthirsty Cú Chulainn with Christ or agnostic Jacobin Wolfe Tone with the holy patron of the island - St Patrick. Mickiewicz undertook a similar task in his writings, claiming that the messianic leader is to combine "the spirit of Christ" with "the spirit of Napoleon". His description of the messianic figure - bridging different and often antithetical traditions by means of his charismatic power, can easily be ascribed to Pearse as well:

This man will have the zeal of the apostles, the devotion of the martyrs, the simplicity of the monks, the audacity of the men of 1793 , the firm unshakeable and overwhelming valour of the soldiers of the Grande Armée, and the genius of their leader ${ }^{30}$.

The concept of a great man re-presenting (in the original sense of the Latin repraesentatio) or incarnating the whole community in himself, points to the crucial tension of Romantic messianism. Mazzini and Michelet ascribed messianic qualities to people as a whole: "Messiah will be a whole people, free, great and bound together by a single thought and great love ${ }^{31}$." Pearse himself only uses the word "Messiah" in his essays once - almost echoing Mazzini:

The Gaelic League was no reed shaken by the wind, no mere vox clamantis: it was a prophet and more than a prophet. But it was not the Messiah. I do not know if the Messiah has yet come, and I am not sure that there will be any visible and personal Messiah in this redemption: the people itself will perhaps be its own Messiah, the people labouring, scourged, crowned with thorns, agonising and dying, to rise again immortal and impassable ${ }^{32}$.

Nevertheless, as mentioned above, Pearse's works are centred on specific messianic figures, from Cú Chulainn to Tone and from Emmett to MacDara the protagonist of The Singer. Again, it seems that among three "great messianists", Mickiewicz remains the closest to Pearse's thinking, as he directly opposes Michelet and Mazzini, claiming that "the essence of Messianism points to a single man, Polish Messianism ascribes to its nation a mission that is however represented by a single person ${ }^{33}$ ". Even if divine qualities are repeatedly ascribed to the people as a whole, Pearse's writings remain focused on charismatic individuals who perform basic messianic functions: revealing and realising, preaching and acting, and who receive their power simultaneously from above and below. Such a leader is an individual lifted above the multitude: "the Man-Word, the organ

\footnotetext{
30. Walicki, Filozofia i mesjanizm, p. 54.

31. Talmon, op. cit., p. 265.

32. Pearse, op. cit., p. 91.

33. Rojek, op. cit., p. 39.
} 
of God's revelation" whose mission is "to lead the lesser and weaker brethren", as Talmon describes Mickiewicz's concept ${ }^{34}$. In a similar vein, the speaker from Pearse's poem Rebel posits himself "in between" the people and the divine, being the One who is "of the people" and "understand[s] the people" but was also

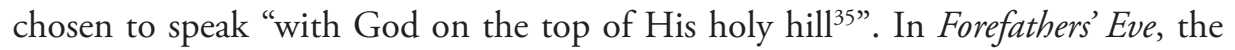
famous vision announcing the revelation of the Messiah ends with his cryptic mystical name - "Forty and Four". As some critics argue, here Mickiewicz uses "Christ's number", i.e. thirty-three, yet multiplies it because the Messiah absorbs the people into himself; he is at once one and multitude ${ }^{36}$. He absorbs into his own self the sufferings of the multitude like the protagonist of Forefathers' Eve who exclaims: "My name is million/because for millions do I love/and suffer agonies" and Pearse's Rebel claiming: "My heart has been heavy with the sorrow of mothers, my eyes have been wet with the tears of the children ${ }^{37}$."

\section{圈 Messianism of "the little world in itself"}

Seamus Deane called Pearse "the last romantic in Irish politics ${ }^{38 "}$ and undoubtedly - ethical radicalism, anti-rationalism, an eschatological vision of history and an inclination towards hero-worship provide the common ground for the prophets of Irish and Polish national messianism. Nevertheless, when we attempt to apply to Pearse's writings three central features of Mickiewicz's messianism (millennium, mission and passion), we are confronted with considerable differences.

Mickiewicz's messianism is a concept which consciously transcends national boundaries and aiming at universal significance. Poland is the "Christ of nations" due to the fact that its sacrifice is to trigger a general Pan-European movement towards regeneration. In the case of Pearse, the only traces of messianism in its universal sense, ascribing a special spiritual mission to the Irish, may be detected in Pearse's earliest essay, where he claims:

The Gael is not like other men; the spade, and the loom, and the sword are not for him. But a destiny more glorious than that of Rome, more glorious than that of Britain awaits him: to become the saviour of idealism in modern intellectual and social life, the regenerator and rejuvenator of

34. Talmon, op. cit., p. 273.

35. Séamas Ó Buachalla (ed.), The Literary Writings of Patrick Pearse, Dublin, Mercier Press, 1979; Adam Mickiewicz, Dziady. Część Trzecia, Warszawa, Czytelnik 1983.

36. Jacek Salij, "Biblijna idea męczeństwa w III części”, Dziadów, Rozpacz pokonana, Poznań, W drodze, 1983, p.155-172.

37. Patrick Pearse, "The Rebel", The Literary Writings..., p. 25-27.

38. Seamus Deane, "Heroic Styles. The Tradition of an Idea", Theorizing Ireland, Ed. Claire Connolly, New York, Palgrave Macmillan, 2003. 14-26. 
the literature of the world, the instructor of the nations, the preacher of the gospel of nature-worship, hero-worship, God-worship - such ... is the destiny of the Gael ${ }^{39}$.

In Pearse's later works, the focus on the Irish struggle for cultural and political sovereignty erases even those rare ventures into the zone of "missionism", undoubtedly influenced by a contemporary mixture of "Celtic twilight" (Yeats's "house of ancient idealism") and "mainstream" Catholicism (Ireland as the most faithful member of the Church) creating a common rhetoric of Irish "exceptionalism". Conversely, Pearse's vision has a decisively national character. The drama of the fall, sacrifice and redemption is staged within the microcosm of the nation, without any attempt to widen its message. Instead, the notion and vocabulary of a divinely inspired mission is transposed to the chosen group or to a single individual within the nation. Pearse's thought may be summed up by a quote from Geoffrey Keating which he repeatedly invokes: it describes Ireland as a "domhan beag intti féin" - "a little world in itself ${ }^{40 "}$.

The perspective of the "little world in itself" also shapes Pearse's position in the context of messianic eschatology. The mission of the elected individual or nation is underlined by the all-pervasive notion of the "ripeness of time", the expectation of the decisive moment which in the Gospel is highlighted by the linguistic shift from chronos to kairos. Whereas Mickiewicz's is a mystical vision of the reign of Freedom across Europe resulting from Poland's redemptive sacrifice, Pearse remains rather modest as far as the "Thousand Year Kingdom" of regained Irish freedom is concerned ${ }^{41}$. On the other hand, there is a definite and growing inclination towards apocalyptic language in Pearse's essays as the Rising is approaching. Pearse demonises the British Empire as the worst tyranny in history, attempting to turn the imminent conflict into a battle between the forces of light and darkness. He escalates his accusations against the Ireland of the time, stressing that the nation faces the ultimate chance to preserve its very existence as a separate entity. Finally, he points to the approaching decisive moment, the intersection between the divine and historical time. In "Peace and the Gael", the language of the apocalypse provides metaphorical cover for the message of the imminent revolution and national deliverance:

39. Patrick Pearse, "Intellectual Future of the Gael", Collected Works of Padraic H. Pearse III, Dublin, Phoenix, 1919, p. 231.

40. Patrick Pearse, "Ghosts", Political Writings..., p. 228.

41. Especially if we do not take too seriously his tongue-in-cheek vision of "Ireland in 2006" from one of his articles in An Claideamb Soluis, with Irish acquiring the status of one of the major world languages and Dublin humming with outdoor cafés due to the "mediterraneanisation" of the climate (Patrick Pearse, "In My Garden", An Claideamh Soluis / Builleachánan Oireachtais, August 1906, p. 1-2.) 
Christ's peace is lovely in its coming, beautiful are its feet on the mountains. But it is heralded by terrific messengers; seraphim and cherubim blow trumpets of war before it. We must not flinch when we are passing through that uproar; we must not faint at the sight of blood. Winning through it, we (or those of us who survive) shall come unto great joy ${ }^{42}$.

His final essay ends in a similar apocalyptic vein - with a call: "The day of the Lord is here".

Nevertheless, compared to the mystical exaltation of Mickiewicz, Pearse seems to employ apocalyptic vocabulary simply as a rhetorical device. On the other hand, he creates an analogy between the universal Christian story and the "little world" of Ireland so consistently, from the community of the nation based on the same principles as the community of the Church ("Ghosts") to "one man saving the nation" as one Man redeemed the world (The Singer), that it is difficult not to discern a kind of "mystical subsidiarity" between two levels, universal and national. In order to attempt to gain an understanding of their relation, we must turn to the final and most prominent feature of Mickiewicz's and Pearse's thought: the idea of self-sacrifice.

\section{圈 Redemptive sacrifice: between metaphor and figura}

"The Poles revealed to the world the idea of messianic sacrifice" - wrote Russian philosopher Nikolai Berdaiev ${ }^{43}$. It was the oppression of Poland under imperial rule that triggered the growth of Mickiewicz's messianism and it was around the image of Calvary and its collective repetition that the idea was clarified in Forefathers' Eve and in The Books. His primary aim was to give meaning to the suffering and defeat by connecting the sacrifice of Poland and the sacrifice of Christ. The nature of this connection, the meaning of the image of the "Christ of nations", remains one of the most disputed themes of Polish intellectual history. Is it only a metaphor, treating the Polish nation as a collective subject whose fate resembles the fate of Christ and draws the spiritual power of endurance from this mystical parallel, thus being a perfectly orthodox, albeit collective, form of imitatio Christi? Or is it, on the contrary, a blasphemous usurping of the messianic status which actually reverses the logic of the figural understanding of history and turns Christ's death and resurrection into a mere type (figura) of future happenings?

Drawing analogies between the fate of Ireland and the story of Calvary is almost commonplace in the nationalist press of the period. In The Catholic Bul-

42. Pearse, "Peace and the Gael", Political Writings..., p. 218.

43. Rojek, op. cit., p. 40. 
letin (January 1916), Mary Butler speaks of the "martyred" Irish nation: "It has trod the road to Calvary, and will surely emerge into the glory of the resurrection ${ }^{44}$." We may also invoke Desmond Ryan's comment of the staging of Pearse's Passion Play in the Abbey a few years earlier:

Some of us, too, thought, though to many it may seem an irreverence, that our national and individual struggle was in ways a faint reflection of the Great One just enacted. Is it not so? The Man is crucified as the $\mathrm{Na}-$ tion, and the Soul moves slowly, falteringly towards the Redemption. ${ }^{45}$

The Calvary metaphor is used here and in countless other places - as de Blácam has it - "daringly yet with reverence". Pearse also always presented his ideas as perfectly in tune with the doctrine, attempting to be "daring" and "reverent" at the same time.

Nonetheless, both Mickiewicz and Pearse also differ from the common nationalist discourse of their time, exemplified here by de Blácam or Butler. The tension between the metaphor and figura seems intensified to the highest possible degree, suggesting that we may be dealing with the relation of identification (substitution, complementation) rather than a mere comparison of events. The final lines of The Singer, mentioned at the beginning of this essay, may be on a par with the ambiguity of Mickiewicz's vision of Poland's crucifixion by the emperors. As Augustine Martin sums up,

Pearse's achievement was that he transferred the concept from the region of metaphor to the region of actuality: the patriot's cause WAS a holy one; the revolution he foresaw was to be IN FACT a holy war; the spilling of the patriot's blood was to be IN FACT redemptive. ${ }^{46}$

In Forefathers' Eve, the vision of Priest Peter of the coming of the messianic leader ends with the angelic choir singing an "Easter chant" and, of course, the symbolism of Easter also provides a framework for the coda of Pearse's writings. In their works, both Mickiewicz and Pearse consistently employ not only the story of Calvary but also the transformative symbolism of the Eucharist, there by strengthening the identification of the sacrifice of Christ with the national hero. Sheridan Gilley may thus claim - echoing Fr. Shaw's accusations - that "Pearse's sacrifice was magnificent, but hardly Christian ${ }^{47}$ ". The protagonist of The Singer is a charismatic messianic leader, prophet, revolutionary and saviour in a single

44. Mary Butler, "Some Traits of the Catholic Gael", The Catholic Bulletin VI, n 1, p. 103.

45. Desmond Ryan, The Story of a Success, Dublin, Phoenix, 1919, p. 108.

46. Martin, op. cit., p. 39.

47. Sheridan Gilley, "Pearse's Sacrifice. Christ and Cuchulain Crucified and Risen in Easter Rising". Sacrifice and Redemption. Durham Essays in Theology, Ed. S.W. Sykes, Cambridge, Cambridge University Press, 1991, p. 218-234. 
person, whose character is closely modelled on Christ, yet whose sacrifice is conducted in the very specific, "tribal" context of the struggle between the Gael and the Gall. Thus it may illustrate the transformation towards "national Messianism" in a more "Talmonian" sense of a substitute for Christianity.

Talmon's strict juxtaposition of Christianity and national does not provide an adequate explanation for countries like Ireland or Poland, in which religion was a natural ally rather than an opponent of the nationalist movement. At least in the initial phase of its development, revolutionary national messianism is bound to draw inspiration and adopt to its own aims the discourse intimately known to the majority of the members of the nation. Mickiewicz in his Books and Pearse may both be considered to be representatives of the early phase of this development. The overwhelming inspirational power behind their conceptualisation of the national struggle is derived and firmly rooted in the specifically Catholic imagery and symbolism. They both consider themselves to be members of the Church and attempt to work with the religious discourse "daringly, yet with reverence". Their drive to identify the cause of the nation with the "cause of Christ" is constantly checked by the orthodox urging to relativise this identification: Mickiewicz comes abruptly from the heights of the eschatological vision to remind the reader very clearly that the "Polish nation is not divine as Christ, so its soul wandering through wilderness may go astray ${ }^{48 ”}$. In “The Coming Revolution”, Pearse claims: "peoples are divine and are the only things that can properly be spoken of under figures drawn from the divine epos" - at once prophesying heresy (divine nature of a nation) and disclosing the metaphorical nature of this relation ${ }^{49}$.

A major relativising factor in Pearse's writing is, however, the conscious limitation to the microcosm of "the little world in itself", the principle of "mystical subsidiarity" which does not attempt to replace or deny the higher level of universal Christian history. When Mac Dara rises to perform his messianic sacrifice, his words are "One man can free a people as one Man redeemed the world". His act is thus not a cancellation of the universal Christ's sacrifice but its repetition on the "lower ontological level" ("a people" versus "the world").

In Andrzej Walicki's words, messianism is a gradable quality ${ }^{50}$. Pearse cannot be ranked alongside the major figures of Romantic national messianism - Michelet, Mazzini or Mickiewicz- because his vision remains enclosed in the exclusively Irish context. It is highly improbable that Pearse did not come across Mickiewicz's texts published in the nationalist press of the period preceding the Rising, though there are no references to this author in his oeuvre. He shares with Mickiewicz a basic inclination towards a particular vision of man, nation and history. Moreover,

48. Mickiewicz, Księgi narodu..., p. 224.

49. Patrick Pearse, op. cit., p. 92.

50. Walicki, Filozofia i mesjanizm, p. 17. 
Pearse is linked to Mickiewicz through both their uneasy relationship to Catholic orthodoxy, and their attempt (however unsuccessful) to inscribe their revolutionary narrative into the framework set by the Catholic doctrine. Therefore, our testing Pearse's variety of national messianism against the ideal type represented by the Polish poet, provides illuminating insights into the combination of daring and reverence towards the Catholic dogma that became a characteristic feature of radical Irish nationalism in the following century. 